Khazanah: Jurnal Studi Islam dan Humaniora

ISSN: 0215-837X (p); 2460-7606 (e), Vol. 18 (1), 2020, pp. 25-48

DOI: 10.18592/khazanah.v18i1.3527

Submit :19/03/2020 Review : 08/05/2020 Publish : 20/06/2020

\title{
PRINSIP LIBERALISME DALAM METODOLOGI TAFSIR FEMINIS: PEMBACAAN PADA KARYA KARYA HUSEIN MUHAMMAD
}

\author{
Eni Zulaiha; B Busro \\ UIN Sunan Gunung Djati Bandung \\ enizulaiha@uinsgd.ac.id; busro@uinsgd.ac.id
}

\begin{abstract}
This study examines the use of liberal principles in Husein Mubammad's works on Quramic interpretation which are found when uses new concepts of the Sciences of the Qur'an. This new concept is used as an ontological view when he interprets Qur'anic verses regarding human rights and gender relations. The liberal principles that Husein Muhammad uses have clear parameters and do not neglect the basic rules of interpretation itself. Through a qualitative approach with descriptive method, research on literature and interviews, this study confirms that the liberal principles used by Husein Mubammad, in addition to using gender justice analysis, are also produced among others through a re-understanding of the rules of interpretation such as asbâb nuحul, nâsikh mansûkh, ta wil, mubkam-mutasyâbih, makkiyah madaniyyah. The redefinition of the rules of interpretation is then used as the basis when he makes the interpretation of the Qur'an so that the results of the interpretation are different when compared to interpretations that have been developed among Muslims. As a result, his interpretation is not only laden with religious messages, but also becomes part of the expression of feminist kiyai identity in the development of interpretations in Indonesia.
\end{abstract}

Keywords: Liberalisme; Tafsir Feminis; Ta’wil; Nasikh Mansukh; Asbâb Nuح̂ûl

\begin{abstract}
Abstrak: Artikel ini memfokuskan pada masalah penggunaan prinsip liberalisme dalam karya penafsiran Husein Muhammad yang terlihat pada saat penggunaan konsep baru tentang beberapa kajian ulum Alqur'an. Konsep baru ini dijadikannya sebagai pandangan ontologis saat melakukan penafsiran pada Alqur'an tentang HAM dan relasi gender. Prinsip-prinsip liberalisme yang digunakannya memiliki parameter yang jelas dan tidak menanggalkan kaidah-kaidah pokok dari panafsiran itu sendiri. Melalui pendekatan kualitatif dengan metode deskriptif, book research dan wawancara, artikel ini menegaskan bahwa prinsip-prinsip liberalisme yang digunakan oleh Husein Mubammad selain menggunakan analisis keadilan gender, juga antara lain dihasilkan melalui pemahaman ulang terhadap kaidah-kaidah penafsiran seperti asbâb nuzul, nâsikh mansûkh, ta wil, mubkam-mutasyâbih, makkiyah madâniyyah. Redefinisi pada kaidah penafsiran ini kemudian dijadikan dasar saat ia melakukan penafsiran Alqur'an sehingga hasil tafsirannya berbeda jika dibandingkan tafsiran yang berkembang di kalangan umat Islam. Hasilnya, tafsirnya bukan hanya sarat dengan pesan keagamaan, tetapi juga menjadi bagian dari ekspresi identitas kiyai feminis dalam perkembangan tafsir di Indonesia.
\end{abstract}

Kata kunci: Liberalisme; Tafsir Feminis; Ta’wil, Nâsikh Mansûkh, Asbâb Nuqû̉l

\section{Pendahuluan}

Liberalisme dan feminisme merupakan dua istilah yang sudah lama diperbincangkan, yakni sejak arus globalisasi masuk ke dunia Islam. Tepatnya sekitar abad ke 20 M. Liberalisme merupakan istilah yang memiliki beragam arti. Semuanya 
berkaitan dengan kebebasan. Namun secara etis dinilai berbeda. Menurut Ahmad Fauzi, kaum liberal memiliki pandangan bahwa setiap individu yang dilahirkan mempunyai kebebasan untuk bertindak melalui pertimbangan logika pemikiran sesuai dengan apa yang mereka harapkan. Secara singkat liberalisme memfokuskan pada kebebasan dalam diri individu dan mendorong lahirnya kemajuan di bidang sosial, melalui sebuah pemikiran dan tindakan sosial. ${ }^{1}$ Mereka meyakini bahwa kebebasan dapat melahirkan rasa tanggung jawab dan optimisme menuju kehidupan sosial masyarakat yang cerah (enlightment). ${ }^{2}$ Meskipun pembahasan liberalisme pada awalnya seputar filsafat politik, namun ia tidak terpisah dan menjadi bagian dari liberalisme sebagai falsafah, kepercayaan (creed), dan cara hidup. ${ }^{3}$ Oleh karena itu, liberalisme hakikatnya bertujuan menghidupkan sistem nilai yang dianggap paling ideal dalam kehidupan sosial manusia sehingga dapat memunculkan sistem nilai yang berbeda. ${ }^{4}$ Kajian tentang liberalisme dalam sudut ilmu memang menjadi kompleks, utamanya pada tataran konseptual. Oleh karena itu harus dibedakan antara konsep mind (pikiran) dengan posisi teori liberalisme. Untuk melihat persoalan sosial diperlukan liberal mind yakni sikap dan pikiran yang terbuka, guna menentukan teori liberalisme yang mana yang paling relevan dengan masalah yang sosial yang dihadapi. ${ }^{5}$ Kaum liberal memberikan penekanan khusus terhadap kebebasan sebagai ide tertinggi individu manusia dalam menentukan wacana perdebatan di masa yang akan datang. ${ }^{6}$

Liberalisme dalam dimensi agama, lebih memfokuskan pada wacana kebebasan berpikir. ${ }^{7}$ Liberalisme pada penafsiran kitab suci tidak bermaksud menyingkirkan tuhan, tetapi lebih pada cara yang ditempuh patuh pada prosedur ilmu pengetahuan. Orang orang liberal saat menafsirkan kitab suci tentu akan lebih taat pada aturan prosedur penelitian ilmiah. ${ }^{8}$ Oleh karena itu, pada umumnya liberal berarti orang-orang yang berani mempertanyakan dan mengkritisi doktrin teologi. ${ }^{9}$ sedangkan paradigma yang bersifat liberal ini dilakukan sebagai sebuah koreksi terhadap penafsiran tekstual yang pada tataran sosiologis, tidak jarang telah

\footnotetext{
${ }^{1}$ Paul Edwards, ed., The Encylopedia of Philosophy (New York: Macmillan Publishing Co, Inc and Fress Press, 1967), 548.

${ }^{2}$ Frits Bolkestein, Liberalisme Dalam Dunia Yang Tengah Berubah (Jakarta: Sumatra Institute, 2006), 55.

${ }^{3}$ Khalif Muammar A Harris, "Islam Dan Liberalisme: Antara Mașlahah Dan Mafsadah," Jurnal Akidah \& Pemikiran Islam 20, no. 2 (2018): 1-52.

${ }^{4}$ Ahmad Fauzi, "Konstruksi Model Pendidikan Pesantren: Diskursus Fundamentalisme Dan Liberalisme Dalam Islam," Al-Tahrir: Jurnal Pemikiran Islam 18, no. 1 (2018): 85-110.

${ }^{5}$ Ulil Abshar Abdallah, Menjadi Muslim Liberal (Jakarta: Nalar, 2005), 3-4.

${ }^{6}$ Edward Maofur, Mohd Yakub, and Zulkifli Mohd Yusoff, "Pengaruh Liberalisme Terhadap Kajian Al-Qur'an Di Indonesia," Jurnal Usuluddin 40 (2014): 1-26.

${ }^{7}$ Munif Zariruddin Fikri Nordin, Suhanim Abdullah, and Marzalina Mansor, "Liberalisme Agama Dalam Analisis Wacana Sisters in Islam Di Malaysia” (Universiti Utara Malaysia, 2012); Muh In'amuzzahidin, "Konsep Kebebasan Dalam Islam," At-Taqaddum 7, no. 2 (2017): 259-76; Robby Habiba Abror, "Makna Kebebasan Berpikir Dalam Diskursus Pemikiran Islam Kontemporer," UNISIA 38, no. 84 (2018): 38-47.

8Budhy Munawar-Rachman, Argumen Islam Untuk Liberalisme (Jakarta: Grasindo, 2010), 163.

${ }^{9}$ Budhy Munawar-Rachman, Reorientasi Pembaruan Islam: Sekulerisme, Liberalisme Dan Pluralisme, Paradigma Baru Islam Indonesia (Jakarta: LSAF dan Paramadina, 2010).
} 
berimplikasi pada stigmatisasi terhadap orang atau kelompok lain. Seperti stigmatisasi murtad, kafir, musyrik dan stigmatisasi pada perempuan. Menjadi liberal artinya bagaimana seseorang dapat memahami teks dengan keluar dari penjara teks melalui bacaan kontekstual yang rasional. ${ }^{10}$ Sedangkan liberalisasi adalah konsep tentang kebebasan menuju nilai kemanusiaan yang hakiki, yakni konsep mendapatkan keadilan sebab pada setiap masyarakat selalu menyimpan keinginan untuk bebas dari tekanan sistem yang ada. ${ }^{11}$

Sampai batas ini, dapat dipahami ternyata liberalisme faham yang bersifat positif dan mendatangkan akibat yang positif pula. Liberalisme dalam pemahaman teks agama adalah paham yang mendorong orang berani mempertanyakan lagi tafsir tafsir lama yang tidak taat prosedur ilmu. Yakni upaya dan pendekatan memahami teks suci dengan menggunakan paradigma-metodologis yang kontekstual, bukan tekstual dengan pola berpikir intersubjektif. ${ }^{12}$ Inilah liberalisme yang dimaksudkan dalam dalam artikel ini

Sementara itu, pengertian feminisme memiliki multifaces (banyak wajah) dan beragam. Rumusan atau definisi tentang feminisme bukan merupakan state of being. Melainkan state of becoming, yang selalu dinamis. Feminisme yang ingin diwujudkan bukanlah paham atau gerakan pemberontakan terhadap kaum laki-laki. Tetapi lebih pada sebuah paham yang ingin menghormati dan menghargai perempuan. Sehingga hak-hak dan peranan mereka bisa lebih optimal dan setara. Tidak ada diskriminasi, marginalisasi dan subordinasi. ${ }^{13}$

Jika feminisme dipahami seperti pengertian di atas. Menurut hemat penulis, secara normatif teologis, Alqur'an sebenarnya sudah membawa ide-ide feminisme. Sebab banyak ayat Alqur'an yang didapati menekankan prinsip-prinsip keadilan, kebebasan dan persamaan. Juga memberikan perlindungan terhadap kaum perempuan. Hal ini dapat dilihat dalam al-Nisâ'[4]: 58 tentang keharusan memutuskan perkara secara adil. Q.S. al-Nahl [16]: 58-59, dan Q.S. al-Takwîr [81]: 89 tentang kritik dan ancaman Alqur'an terhadap praktik pembunuhan anak perempuan dengan cara dikubur hidup-hidup, dan lain sebagainya. ${ }^{14}$

Jika dirinci lebih detail, penyebab lahirnya tafsir feminis, antara lain datang dari internal ajaran Islam itu sendiri. Yakni, adanya pemahaman dan kesadaran tentang ajaran Islam yang adil bagi semua manusia. Pemahaman dari kalangan mufassir kontemporer yang berpandangan bahwa pada dasarnya agama Islam

${ }^{10}$ Zuhairi Misrawi and Noviriantoni, Doktrin Islam Progresif Memahami Islam Sebagai Ajaran Rahmat (Jakarta: LSIP, 2004), 127-28.

${ }^{11}$ Munawar-Rachman, Reorientasi Pembaruan Islam: Sekulerisme, Liberalisme Dan Pluralisme, Paradigma Baru Islam Indonesia, 486.

${ }^{12}$ Amin Abdullah, Islamic Studies Di Perguruan Tinggi Pendekatan Integratif Interkonektif (Yogyakarta: Pustaka Pelajar, 2006), 67.

${ }^{13}$ Kamla Bashin and Nighat Said Khan, Persoalan Pokok Mengenai Feminisme Dan Relevansinya (Jakarta: Gramedia, 1995), 4.

${ }^{14}$ Untuk selanjutnya, diskursus tentang perlindungan Alquran terhadap perempuan dapat dibaca dalam Syeikh 'Abdullah bin Ibrahim Jarullah, Tanggung Jawab Wanita Muslimah, trans. Mukhtar Nasir (Solo: Pustaka Mantiq, 1996), 17-24. 
menegaskan kesetaraan antara laki-laki dan perempuan. Meski misalnya, Alqur'an menggunakan bahasa (ungkapan) yang kadangkala secara literal menunjuk pada struktur yang hirarkis. Namun secara moral, ia justru ingin menghilangkan subordinasi yang dialami oleh perempuan pada masa-masa sebelum Islam. Jadi sesungguhnya, ungkapan Alqur'an adalah ungkapan yang penuh dengan pesan pembebasan, sehingga penulis tertarik untuk mengkaji tentang tafsir feminis berdasarkan prinsip-prinsip liberalisme. ${ }^{15}$

Salah seorang tokoh yang memberikan perhatian besar pada masalah ini adalah Husein Muhammad. Ia dikenal luas sebagai tokoh feminisme yang memberikan penafsiran dengan nuansa baru terkait feminisme. Ia dipandang satusatunya kyai feminis Indonesia yang tak pernah merasa lelah membela perempuan. Ia berjuang mendobrak kemapanan pemahaman relasi gender yang ada. Pandangannya banyak berbeda dengan pandangan keagamaan arus utama. Terutama ketika membahas fikih terkait persoalan kemanusiaan dan perempuan.

Namun demikian, pandangan dan penafsiran Husein Muhammad bukan tidak memiliki asumsi paradigmatif yang sistematis. Bermodal pada kemampuan yang baik dalam keilmuan tafsir, fikih dan bahasa Arab, sebagai hasil dari pendidikan pesantren tradisional yang kental dengan pembelajaran kitab kuning, pada akhirnya telah dengan jelas membentuknya menjadi feminis laki-laki yang memberikan warna tersendiri pada kajian perempuan. ${ }^{16}$ Faktor lainnya yang telah turut mendorongnya, adalah keberaniannya yang telah sedikit banyak mendasarkan pemahaman pada kaidah-kaidah ilmu tafsir dengan mengikuti pendapat para ulama ulûm Alqur'an kontemporer sendiri, seperti tentang asbâb nu₹ûul, nâsikh mansûkkh, ta'wûl, dan ayat makkiyah mad niyyah.

Kajian tentang pemikiran Husein Muhammad dan tafsir feminis telah dilakukan oleh banyak sarjana. Misalnya artikel Yusuf Rahman yang menyimpulkan bahwa dalam menafsirkan Alqur'an Husein Muhammad telah mendasarkan terlebih dahulu pada prinsip tauhid yang berelasi pada pembahasan lebih umum tentang kemanusiaan universal. Ia juga menjelaskan bahwa Husein memiliki beberapa prinsip dalam menafsirkan ayat-ayat relasi gender. Namun, belum mendedah secara jelas pada prinsip liberalisme yang ada dalam karya karyanya. ${ }^{17}$ Artikel Zulaiha tentang tafsir feminis ${ }^{18}$ dan prinsip penafsiran Husein Muhammad ${ }^{19}$ menjelaskan seputar paradigma dan standar validitas tafsir feminis, juga penjelasan tentang prinsip

\footnotetext{
${ }^{15}$ Asghar Ali Engineer, Islam Dan Teologi Pembebasan, Terj. Hairus Salim (Yogyakarta: LKIS, 1991), 13.

${ }^{16}$ Eni Zulaiha, "Analisa Gender Dan Prinsip-Prinsip Penafsiran Husein Muhammad Pada AyatAyat Relasi Gender,” Al-Bayan: Jurnal Studi Al-Qur 'an Dan Tafsir 3, no. 1 (2018): 1-11.

${ }^{17}$ Yusuf Rahman, "Feminist Kyai, KH Husein Muhammad: The Feminist Interpretation on Gendered Verses and the Qur' n-Based Activism," Al-Jami'ab: Journal of Islamic Studies 55, no. 2 (2017): 293-326.

${ }^{18}$ Eni Zulaiha, "Tafsir Feminis: Sejarah, Paradigma Dan Standar Validitas Tafsir Feminis," AlBayan: Jurnal Studi Ilmu Al-Qur'an Dan Tafsir 1, no. 1 (2016): 17-26.

${ }^{19}$ Zulaiha, "Analisa Gender Dan Prinsip-Prinsip Penafsiran Husein Muhammad Pada AyatAyat Relasi Gender.”
} 
penafsiran Husein Muhammad secara umum. Susanti menegaskan bahwa Husein Muhammad adalah seorang feminis liberal karena ia tidak menyarankan untuk mengubah Alqur'an atau menggantikan posisi laki-laki dengan perempuan dalam segala peran, yang diperlukan cukup melakukan penafsiran ulang pada ayat-ayat yang telah ditafsirkan secara bias. ${ }^{20}$ Samsul Zakaria yang menyoroti kepemimpinan perempuan dalam perspektif hukum Islam, dalam makalah ini ditegaskan bahwa Husein Muhammd dan Musdah Mulia sama-sama mendukung perempuan menjadi pemimpin di wilayah domestik dan publik, bedanya argumentasi Husein Muhammad didukung dengan berbagai kajian kitab kuning sedangkan Musdah banyak menganalisa dengan HAM. ${ }^{21}$ Sementara itu Muhammad Tobroni, menemukan bahwa kajian seksualitas dalam al-Qur'an menurut Husein Muhammad tidak sama dengan kajian ulama klasik, karena pemikiran Husein Muhammad didasarkan pada persamaan hak antara laki-laki perempuan dalam segala aspek kehidupan yang kemudian berpengaruh pada analisisnya tentang seksualitas. ${ }^{22}$ Penelitian ini bermaksud melanjutkan dan melengkapi kajian di atas.

Kajian tentang feminisme dalam berbagai perspektif juga telah dilakukan, seperti yang dlakukan oleh M. Noor Harisudin menjelaskan bahwa kajian fikih perempuan di Indonesia kini terbagi pada kelompok feminis dan konservatif. Meski materi yang dikaji sama, namun melalui metodologi yang berbeda kedua kelompok ini memilki kesimpulan yang berbeda pula. ${ }^{23}$ Muhammad Hasbi ${ }^{24}$ dan Nur Rofiah ${ }^{25}$ menuliskan kekerasan pada perempuan secara kajian agama dan sosiologi bersumber pada ketidaksetaraan posisi perempuan dengan laki-laki baik yang dipengaruhi oleh budaya patriarkhal ataupun budaya dominatif lainnya. Penelitian tersebut memperkuat asumsi penulis, bahwa paradigma patriarkis, akan mengakibatkan terjadinya hasil pemahaman yang berbeda. Sementara itu, artikel yang tergolong menentang pemikiran feminis pada umumnya diantaranya, artikel Adian Husaini dan Rahmatul Husni menjelaskan bahwa teks-teks agama Islam yang ditafsirkan ulang oleh kaum feminis Islam itu masih menyisakan problem metodologis dan ketidakjelasan konsep adil dari kalangan feminis muslim. ${ }^{26}$ Artikel ini bermaksud mengkritik tulisan Adian Husaini dan Rahmatul Husni di atas.

\footnotetext{
${ }^{20}$ Susanti Susanti, "Husein Muhammad Antara Feminis Islam Dan Feminis Liberal," Teosofi: Jurnal Tasawnf Dan Pemikiran Islam 4, no. 1 (2014): 197-219.

${ }^{21}$ Samsul Zakaria, "Kepemimpinan Perempuan Dalam Persepektif Hukum Islam (Studi Komparatif Antara Pemikiran KH. Husein Muhammad Dan Prof. Siti Musdah Mulia)," Khazanah 6, no. 1 (2013): 65-97.

${ }^{22}$ Muhammad Tobroni, "Makna Seksualitas Dalam Al-Qur'an Menurut Husein Muhammad," Al-A'raf: Jurnal Pemikiran Islam Dan Filsafat 14, no. 2 (2017): 219-38.

${ }^{23}$ M Noor Harisuddin, "Pemikiran Feminis Muslim Di Indonesia Tentang Fiqh Perempuan," Al-Tabrir: Jurnal Pemikiran Islam 15, no. 2 (2015): 237-62.

${ }^{24}$ Muhammad Hasbi, "Kekerasan Perempuan Dalam Wacana Pemikiran Agama Dan Sosiologi," Al-Tabrir: Jurnal Pemikiran Islam 15, no. 2 (2015): 389-410.

${ }^{25}$ Nur Rofiah, "Kekerasan Dalam Rumah Tangga Dalam Perspektif Islam," Wawasan: Jurnal Ilmiah Agama Dan Sosial Budaya 2, no. 1 (2017): 31-44.

${ }^{26}$ Adian Husaini and Rahmatul Husni, "Problematika Tafsir Feminis: Studi Kritis Konsep Kesetaraan Gender,” Al-Tabrir: Jurnal Pemikiran Islam 15, no. 2 (2015): 367-88.
}

Khazanah, Vol. 18 (1), 2020 
Sedangkan artikel yang mengkaji tentang liberalisme pernah dilakukan oleh Ahmad Fauzi, menjelaskan bahwa liberalisme memberikan pengaruh positif pada pendidikan pesantren sudah masuk konstruksi model pendidikan pesantren. ${ }^{27}$ Edward Maofur' Mohd Yakub dan Zulkifli Mohd Yusoff menjelaskan liberalisme juga telah memberikan perspektif baru dalam mengkaji kitab suci al-Qur'an di Indonesia. ${ }^{28}$ Secara garis besar, artikel ini bermaksud melanjutkan beberapa studi di atas dengan fokus kajian yang berbeda, yakni lebih memfokuskan pada penjelasan prinsip-prinsip liberalisme yang digunakan oleh Husein Muhammad dalam metodologi tafsir feminis, melalui pembacaan pada karya karyanya. Karena, ternyata prinsip liberalisme ini berpengaruh secara langsung pada hasil penafsirannya.

\section{Metode}

Pendekatan penelitian yang digunakan peneliti adalah pendekatan kualitatif dengan metode deskriptif serta kepustakaan (library research). Pengumpulan data menggunakan metode wawancara dan dokumentasi. Dalam memeriksa keabsahan data menggunakan triangulasi, baik sumber maupun metode. Sedangkan teknik analisis data menggunakan model interaktif Miles \& Huberman dengan siklus mulai pengumpulan data, reduksi data, penyajian data, verifikasi dan penarikan kesimpulan.

\section{Pembahasan}

\section{Biografi Husein Muhammad}

Husein Muhammad itu anak kedua dari 8 bersaudara. ${ }^{29}$ Ia dilahirkan di Cirebon. Tepatnya di Arjawinangun pada tanggal 9 Mei 1953 di lingkungan Pondok pesantren Dar At-Tauhid. Husein kecil belajar agama dan belajar pengetahuan umum di SMPN 1 Arjawinangun. Ia juga sosok anak yang aktif di organisasi dalam dan luar sekolah. Pengalaman ini yang kelak mematangkan pribadinya dan meluaskan pengetahuannya hingga ia menjadi seorang kyai yang open minded..$^{30}$ Pendidikan tingkat atasnya ia tempuh tiga tahun belajar di pesantren Lirboyo. Setelah menjadi sarjana Perguruan Tinggi Ilmu Alqur'an (PTIQ) Jakarta dengan skripsi berjudul Pidana Mati Menurut Hukum Islam, pada tahun yang sama, Husein berangkat ke Kairo Mesir untuk melanjutkan kuliah di pascasarjana Al-Azhar University. Namun, menurut pengakuannya pada penulis, "karena ijazah PTIQ saya dianggap tidak mu'adalah, saya gagal melanjutkan studi di al-Azhar University, saya kemudian memilih belajar bersama para syaikh di sana secara pribadi”. Ia kemudian belajar pada sejumlah syekh di Majma' al-Bubûts al-Islâmiyah milik Univrsitas al-Azhar. Secara formal ia belajar di

${ }^{27}$ Fauzi, "Konstruksi Model Pendidikan Pesantren: Diskursus Fundamentalisme Dan Liberalisme Dalam Islam." Indonesia."

${ }^{28}$ Maofur, Yakub, and Yusoff, "Pengaruh Liberalisme Terhadap Kajian Al-Qur'an Di

${ }^{29}$ Yaitu: 1) Hasan Thuba (almarhum), 2) Husein Muhammad, 3) Ahsin Sakho Muhammad, 4) Ubaidah, 5)Mahsun Muhammad, 6) Azzah Nurlaila, 7) M salaman al-Faries, 8) Elok faiqoh. Wawancara dengan Husein Muhammad tanggal 10 Mei 2018

${ }^{30}$ Wawancara dengan Husein Muhammad tanggal 22 Januari 2017. 
Dirâsat al-Kashâshah (Arabic Special Studies). Dari Dirasat al-Kashâshah ia berkenalan dengan pemikiran Islam modern yang berkembang saat itu, disamping beberapa pemikiran Barat. Setiba di Tanah Air, Husein ditawari untuk mengajar di PTIQ, namun ia lebih memilih pulang untuk mengembangkan pesantren kakeknya.

Husein yang sejak kecil yang sudah terbiasa belajar agama dan melihat pembelajaran kitab kuning, memiliki kematangan dalam persoalan memahami kitab kuning. Pengalamannya kuliah di PTIQ seakan melangkapi kepintarannya untuk dapat tampil sebagai seorang kyai dimasa datang dengan berbekal beberapa keahlian juga kemampuan menghafal Alqur'an sebanyak 30 juz secara sempurna.

Adalah Masdar Farid Masudi, ketua dari lembaga P3M (Perhimpunan dan Pengembangan Pesantrendan Masyarakat) yang pertama kali memintanya untuk mengikuti halaqah dan seminar-seminar yang diadakan oleh P3M. Dari sinilah Husein mulai menerima gagasan-gagasan Islam yang langsung bersentuhan dengan realitas sosial yang selama ini tidak diperoleh Husein di pesantren umumnya. Gagasangagasan Husein berubah menjadi lebih progresif dibandingkan sebelum Husein bertemu dengan Masdar. ${ }^{31}$

Husein Muhammad sosok yang unik, karena ia sosok kyai penghafal Quran dan sangat menguasa ilmu-ilmu Islam tradisional. Ia bukan akademisi, tapi mengenal beberapa pemikiran modern, yang dengan segala upaya dan keterbatasannya tetap menyuarakan pembelaan pada perempuan di even-even nasional maupun internasional.

Sampai tulisan ini dibuat tercatat kurang lebih ada 42 karya Husein tentang wacana-wacana yang sedang ramai didiskusikan, mulai dari HAM-demokrasi, pluralisme, relasi gender, hingga pemikiran tasawuf. Menurut penulis, Husein Muhammad dapat digolongkan sebagai feminis laki-laki. Karena ia laki-laki yang memiliki kesadaran untuk membela perempuan, ia telah mengusung gagasan feminisme dalam aksi dan wacananya. Dalam aksinya ia telah menulis beberapa karya untuk pembelaan pada perempuan sebagai perjuangannya di tataran wacana. Selain itu, ia juga berani meng-counter wacana keagamaan yang bias gender dengan basis keilmuan klasik yang biasa digunakan oleh masyarakat umum dan kalangan dalam pesantren

Secara umum karya-karya Husein dibagi menjadi dua bagian, yaitu: Pertama yang termasuk kategori karya tulis yang dipublikasikan dan kedua, karya-karya yang tidak atau belum dipublikasi. ${ }^{32}$

Konsistensi Husein Muhammad dalam menyuarakan gagasan dalam membela HAM dan gender hingga mengantarkannya memperoleh beberapa penghargaan yang pernah diraihnya:

1. Penerima penghargaan Bupati Kabupaten Cirebon sebagai Tokoh Penggerak, Pembina dan Pelaku Pembangunan Pemberdayaan Perempuan, 2003

2. Penerima Penghargaan dari Pemerintah AS untuk "Heroes Acting To End Modern-Day Slavery". (Trafficking in Person). "Award for Heroisme”, 2006.

${ }^{31}$ M. Nuruzzaman, Kyai Membela Perempuan (Yogyakarta: Pustaka Pesantren, 2005), 118.

${ }^{32}$ Sekitar 42 karyanya sudah dipublikasi oleh beberapa penerbit ternama 
3. The 500 Most Influential Muslims In The World, 2010, hingga 2017, The Royal Islamic Strategic Studies Center,Yordania.

4. Pada tanggal 26 Maret 2019, Husein Muhammad menerima gelar Doktor Honoris Causa dari Fakultas Ushuluddin dan Humaniora Universitas Islam Negeri Wali Songo Semarang. Pemberian gelar ini dipromotori oleh tiga profesor yakni Prof. Dr. KH Nazaruddin Umar, Prof. Dr. Hj Istibsyaroh dan Prof. Dr. Imam Taufiq.

\section{Prinsip Liberalisme Dalam Pemikiran Tafsir Alqur'an Husein Muhammad}

Husein Muhammad oleh Buddy Munawar-Rachman, Jamal Ma'mur dan Yusuf Rahman digolongkan pada kelompok Islam progresif-liberal. ${ }^{33}$ Seperti halnya para pemikir Islam Progresif lainnya, Husein tampak sadar bahwa keberagamaan tak bisa lepas dari pengaruh teks agama berikut penafsirannya. Bahwa pesan Tuhan dalam Alquran itu selalu menciptakan pesan baru, hukum, komunitas dan peradaban baru. Oleh karena itu dibutuhkan kritisisme, mustahil alquran bisa dipahami pesannya secara komperhensif. Pemahaman yang komprehensif hanya dapat dicapai jika memperhatikan kesesuaian antara ajaran dengan pesan orisinal etis Alqur'an. Seperti yang telah dijelaskan di awal bahwa yang dimaksud dengan liberalisme dalam artikel ini adalah paham yang berusaha memahami al-Quran dengan seperangkat paradigma-metodologis yang kontekstual, fungsional dengan pendekatan berpikir intersubjektif. Oleh karena itu ia kemudian meliberalkan beberapa konsep yang terkait dengan metode pemaham teks Alqur'an yakni: pada kajian asbâb al-nuશûul, makkiyyah-madâniyyah, mubkam - mutasyabbih dan juga nâsikh-mansûkh.

\section{Asbâb al-Nuzûl}

Salah satu manfaat mengetahui asbâb al-nuzûl adalah mempermudah pemahaman, dan menghindari kesamaran makna ayat sehingga penggunaannya menjadikan sebuah penafsiran menjadi lebih otentik. ${ }^{34}$ Kalangan muslim progresif telah memberikan alternatif dalam melihat asbâb al-nuચûul. Perlu disadari bahwa di dalam teks senantiasa ada tanda-tanda yang kalau dianalisis dapat menyingkapkan apa yang merupakan sesuatu yang berada di luar teks. Oleh karena itu penyingkapan asbâb al-nuzûul dapat dilakukan dari dalam teks sebagaimana menyingkapkan dalâlah teks dapat dilakukan dengan mengetahui konteks eksternalnya. Asbâb al-nu₹ûl harus bersandar sepenuhnya pada pendekatan sejarah untuk menemukan makna teks dan pada analisis latar sosiologis dimana asbâb al-nuఇûul menjadi bagiannya demi memahami sasaran Alqur'an. Sebab untuk memahami Alqur'an, tak ada bimbingan yang lebih penting dari pada pengetahuan tentang kapan dan dalam situasi apa ayat

\footnotetext{
${ }^{33}$ Munawar-Rachman, Reorientasi Pembaruan Islam: Sekulerisme, Liberalisme Dan Pluralisme, Paradigma Baru Islam Indonesia, 446-507. Lihat juga Jamal Ma'mur, Rezim Gender Di NU (Yogyakarta: Pustaka Pelajar, 2015), 260. Lihat juga Rahman, "Feminist Kyai, KH Husein Muhammad: The Feminist Interpretation on Gendered Verses and the Qur'an-Based Activism."

${ }^{34} \mathrm{Abd}$ Kholid, "Legalitas Riwayat Asbab Al Nuzul Telaah Historis Kontek Turunnya Ayat AlQur'an," Jurnal THEOLOGLA 24, no. 1 (2013): 145-74.
} 
Alqur'an itu diturunkan. ${ }^{35}$

Bagi Husein sendiri asbâb al-nuzûl merupakan kajian sejarah tradisi manusia secara makro (bukan mikro) pada saat turunnya Alqur'an. Artinya mengetahui asbâb al-nu₹ûl berarti memahami nila-nilai universal dari respon Allah pada manusia secara keseluruhan, bukan hanya pada masyarakat Arabia saat itu saja.

Ia menegaskan bahwa kenyataan sejarah Alqur'an ini penting dikemukakan agar dapat dipahami bahwa kitab suci ini senantiasa melakukan dialog secara dinamis dan akomodatif, bernegosiasi dan melakukan interaksi dengan akal dan psikososial masyarakat Arabia pada abad ke-7 M dan subyek audiens yang tunggal. ${ }^{36}$

Oleh sebab itu, bagi Husein, hal yang penting dari kajian asbâb al-nu₹ûul bukan hanya pada kajian riwayat-riwayat tentang peristiwa yang mengiri turunnya ayat Alqur'an. Namun yang terpenting adalah kajian kesejarahan terutama pada persoalan psikososial yakni kaitan teks yang turun dengan keadaan audiens yang selalu berbeda, entah itu kaitannya dengan persoalan audiens masyarakat Mekkah atau masyarakat Madinah.

Rumusan asbâb al-nu₹ûl Husein Muhammad di atas, sebenarnya ingin menegaskan bahwa selama ini telah terjadi kesalahan pemahaman pada maksud ayat Alquran yang diakibatkan karena tidak memperhatikan aspek keterkaitan ayat-ayat Alquran dan pengabaian aspek historis dari ayat ayat itu sendiri.

\section{Nâsikh-Mansûkh}

Dalam kajian tradisional tentang Alqur'an dan syariat Islam, nâsikh-mansûke $h^{37}$ ini berarti verifikasi dan elaborasi berbagai modus pembatalan. Beberapa ketentuan hukum yang berlaku, kemudian dicabut atau berakhir masa pemberlakuannya dan diganti dengan ketentuan hukum lain. ${ }^{38}$ Hal seperti ini, jika dilihat dari sudut pendekatan ilmu hukum adalah hal yang lumrah dan banyak terjadi. Bahwa suatu undang-undang atau peraturan hukum lainnya dicabut atau dinyatakan tidak berlaku lagi, kemudian diganti dengan menetapkan undang-undang atau peraturan lain. Fenomena naskh yang diakui oleh para ulama ini bagi para pemikir Islam Progresif merupakan bukti terbesar adanya dialektika hubungan antara wahyu dan realitas, yakni pertautan antara normativitas dan historisitas. ${ }^{39}$ Bukti tentang hal ini adalah "Tiap ayat yang Kami batalkan, atau Kami jadikan manusia lupa kepadanya, Kami datangkan

${ }^{35}$ Farid Essack, Membebaskan Yang Tertindas, Al-Qur'an Liberalisme Pluralisme, trans. Watung Budiman (Bandung: Mizan, 2000), 89.

${ }^{36}$ Husein Muhammad, Ijtihad Kyai Husein Upaya Membangun Keadilan Gender (Jakarta: Rahima, 2001), xxii.

${ }^{37}$ Kajian ini dimunculkan oleh mayoritas ulama karena adanya ayat-ayat yang dianggap saling bertentangan makna literalnya yang tidak mungkin lagi dapat dikompromikan. Menurut teori ini, ayatayat yang menghapus (nâsikh) adalah ayat-ayat yang diturunkan belakangan. Sementara ayat-ayat yang

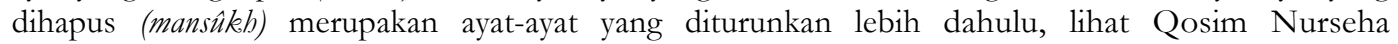
Dzulhadi, "Kontroversi Nasikh-Mansukh Dalam Al-Qur'an," Tsaqofah Jurnal Peradaban 5, no. 2 (2009): 257-88.

${ }^{38}$ M. 'Abid Al Jabiri, Fabmu Al-Qur'an Al-Hakim; Al-Tafsir Al-Wadih Hasbi Tartib Al-Nuqul (Maroko: al-Dar al-Baida’, 2008).

${ }^{39}$ Abdullah, Islamic Studies di Perguruan Tinggi Pendekatan Integratif Interkonektif, 26. 
yang lebih baik atau yang sebanding dengannya. Tidakkah kamu mengetabui babwa Tuban berkuasa atas segala sesuatu?” (Q.2:106).

Menurut Husein Muhammad tentang nâsikh-mansûkh, bahwa terlepas dari teori tentang nâsikh-mansûkh dari para ulama di atas, ia tidak hendak menguraikannya lebih panjang. Kenyataan tersebut baginya telah menunjukan dengan jelas bahwa seluruh ulama mengakui adanya dimensi historisitas teks Alqur'an. Dengan kata lain, teori ini sesungguhnya sedang menunjukkan adanya kehendak perubahan hukum dari satu waktu ke waktu yang lain dan dari satu ruang ke ruang yang lain. Nâsikh merupakan penjelasan keberlakuan hukum. Sepanjang teks-teks Alqur'an diarahkan kepada manusia yang hidup dalam sejarah, maka suka tidak suka teks tersebut akan terlibat dalam dinamika sosialnya. ${ }^{40}$

Meski Husein tampak menghindari perdebatan ulama seputar kajian nâsikhmansûkkh, tetapi pada akhirnya ia menegaskan bahwa nâsikh itu menunjukan penjelasan keberlakuan hukum. Pandangannya tentang hal ini konsekuensi dari pandangan ontologisnya tentang Alqur'an dan tafsir.

\section{Makkiyah dan Madâniyyab}

Pembahasan nâsikh-mansûkh yang telah diliberalkan oleh Husein Muhammad pada gilirannya mempengaruhi pandangan Husein tentang makkizyah dan madâniyya $b^{41}$ yang kemudian diliberalkan juga. Husein menjelaskan bahwa ilmu makiyyah dan madâniyyah merupakan perjalanan kedewasaan awal umat Islam. Dua tipologi ayat dalam Alqur'an menggambarkan perjalanan sejarah Alqur'an turun. Tidak mungkin ayat Alqur'an tanpa mengaitkannya dengan dua fase sejarah yang menjadi latar belakang ayat itu turun, baik ayat-ayat makkiyyah maupun madâniyyah.

Teori makkiyyah dan madâniyyah memperlihatkan dengan jelas bahwa teks-teks Alqur'an diarahkan pada dua konteks sosial dan audiens yang berbeda pada satu sisi dan di sisi lain menunjukkan perkembangan risalah yang sedang terus berjalan. ${ }^{42}$

Menurut Husein, masa Jahiliyyah itu bukan sekedar masyarakat yang tidak mengenal budaya tulis-menulis saja, melainkan sebuah tatanan masyarakat yang tidak mengerti hak-hak manusia yang harus dihormati. Sisi perilaku, Jahiliyyah memiliki ciri perilaku yang menonjol yaitu penindasan terhadap manusia dan pelecehan terhadap perempuan. Hal inilah yang kemudian direspons lebih banyak oleh Alqur'an. ${ }^{43}$

Husein juga menjelaskan bahwasannya Alqur'an yang hadir di tengah-tengah masyarakat yang cenderung tidak hampa aturan, selalu memandang lemah perempuan, dan melecehkan terhadap hak-hak yang dimiliki oleh setiap manusia, ini secara tuntas direspons dan dirubah dalam waktu yang tidak sebentar. Kondisi kebudayaan inilah, yang kemudian berdampak pada ayat-ayat yang turun di Mekkah

${ }^{40}$ Muhammad, Ijtibad Kyai Husein Upaya Membangun Keadilan Gender, xxvi.

${ }^{41}$ Menurut artikel ini, kajian tema ini masih membutuhkan kajian mendalam dengan berbagai pendekatan. Lihat Abad Badruzaman, "Model Pembacaan Baru Konsep Makiyyah-Madaniyyah," Epistemé: Jurnal Pengembangan Ilmu Keislaman 10, no. 1 (2015): 53-76.

42Wawancara dengan Husein Muhammad pada tanggal 8 Juli 2019.

${ }^{43}$ Wawancara dengan Husein Muhammad pada tanggal 08 Juli 2019. 
atau disebut dengan ayat-ayat makiyyah. ${ }^{44}$ Inilah yang yang lebih penting dalam mengetahui kondisi sosio-historis masyarakat Arab sebelum Alqur'an turun. Sebagaimana Alqur'an hadir untuk membimbing, dan mengarahkan dakwah Nabi saw. Kajian tentang makkiyyah dan madâniyyah melalui pendekatan sosial histori menjadikan teks-teks Alqur'an lebih responsif dan lebih hidup dalam dinamika kehidupan bermasyarakat. ${ }^{45}$

Lebih lanjut Husein menganggap bahwa kondisi sosial juga ikut mempengaruhi ayat-ayat Alqur'an itu diturunkan baik di Mekkah maupun di Madinah. Oleh karena itu, makkiyyah dalam pandangan Husein adalah ayat yang turun di Mekkah bersamaan dengan masa diturunkannya Alqur'an, sehingga Husein menempatkan ayat-ayat makkiyyah sebagai periode peletakan pondasi (dasar-dasar) untuk membangun struktur masyarakat baru. Akibatnya, secara umum ayat-ayat makkiyyah dijadikan sebagai prinsip yang pasti bersifat kokoh, ayat-ayat makkiyyah lebih menekankan pada aspek ketauhidan, nilai-nilai kemanusiaan yang bersifat universal, misalnya kesetaraan manusia, keadilan, kebebasan, pluralitas dan penghargaan martabat manusia. Hal ini pada giliran berikutnya, tentu lumrah bila bahasa yang digunakan dalam ayat-ayat makkiyyah menyapa manusia dengan istilah yang terhormat, tanpa melihat ras, suku, warna kulit, gender dan agama. Teks-teks Alqur'an pada periode ini mengandung gagasan yang progresif dan revolusioner. ${ }^{46}$

Sementara Ayat-ayat madaniyah menurut Husein adalah ayat yang diturunkan di Madinah. Umumnya berisi penetapkan aturan-aturan yang lebih rinci, lebih spesifik dan partikular yang menyangkut problem-problem aktual yang dihadapi masyarakat Madinah. Beberapa diantaranya berkaitan dengan hukum-hukum personal, hukum keluarga, dan aturan aturan tentang kehidupan bersama dalam masyarakat plural yang telah terbentuk disana. Ayat-ayat madâniyyah oleh Husein Muhammad dikategorikan pada teks partikular. Yaitu teks -teks yang menunjukan pada kasus tertentu.

Teks partikular muncul sebagai respon atas suatu kasus atau peristiwa, oleh karena itu teks ini bersifat selalu terkait dengan kasus tertentu. Karenanya teks partikular harus dimaknai secara kontekstual. Isu-isu kepemimpinan laki-laki atas perempuan, perwalian perempuan, poligami, kewarisan dan lain lain adalah contoh teks-teks partikular. Ia juga termasuk pada kategori mutasyâbbihât, interpretable, dan dapat dinterpretasikan karena dapat menghasilkan pemahaman yang berbeda-beda. Sedangkan ayat-ayat mutasyâbbihât adalah ayat-ayat yang berkaitan dengan aspek aksiologis tentang bagaimana menetapkan ayat-ayat termasuk dalam kategori muhkam ini. Dengan kata lain, ayat-ayat mutasyâbbihât cenderung bersifat teknispartikular.

Husein menegaskan bahwa tidak ada manusia yang mampu merubah kultural kebudayaan yang sudah mengakar di masyarakat pada saat itu selain Nabi Muhammad saw. dalam waktu yang lama, Alqur'an hadir untuk menjawab

${ }^{44}$ Wawancara dengan Husein Muhammad pada tanggal 08 Juli 2019.

${ }^{45}$ Wawancara dengan Husein Muhammad pada tanggal 8 Juli 2019.

${ }^{46}$ Husein Muhammad and Faqihuddin Abdul Qadir, Modul Kursus Islam Dan Gender; Dawrah Fikih Perempuan (Cirebon: Fahima Institut, 2007), 83. 
problematika yang terjadi pada masyarakat Arabia. Ini akan menunjukkan tentang bagaimana gaya bahasa yang Allah gunakan saat ayat-ayat turun di Mekkah dan ayat yang turun di Madinah. ${ }^{47}$

Beragam pandangan mengenai makkiyyah dan madâniyyah di atas pada intinya menggambarkan bahwa ayat-ayat Alqur'an diarahkan pada dua konteks sosial yang berbeda. Sekaligus pada konteks perkembangan risalah yang sedang berjalan guna merespons dan mengatasi problem-problem yang dihadapi baik masyarakat Mekkah maupun masyarakat Madinah.

Bagi Husein Muhammad, pendapat ulama yang mengkategorikan makkiyyah dan madâniyyah berdasarkan waktu, tempat, atau ciri kata-kata dengan penggunaan yâa ayuballadzina âmnu atau yâ ayubannâs, hal itu hanya menyentuh pada pengetahuan bahwa ayat-ayat itu ditunjukan pada masyarakat audiens Alqur'an yang berbeda. Sekaligus berada pada perkembangan risalah yang sedang berjalan guna merespons dan mengatasi problem sosial, budaya, ekonomi dan politik yang tengah dihadapi masyarakat audiens. Padahal menurut Husein, kenyataan adanya kelompok ayat makkiyyah dan kelompok ayat madâniyyah itu boleh jadi terkait dengan upaya mengembalikan kesadaran audiens tentang pentingnya mendasarkan aturan-aturan sosial pada prinsip-prinsip kemanusiaan universal yang menjadi tujuan agama. ${ }^{48}$

Contohnya, QS. Al-Baqarah [2]: 256 tentang kebebasan ("tidak adanya paksaan agama"), QS. Al-Hujurât [49]: 13 tentang kesetaraan manusia ("yang paling mulia di antara kamu di mata Allah adalah yang paling bertaqwa"), QS. Al-Isrâ' [17]: 70 tentang menghormati martabat manusia, QS. Al-Mâidah [5]: 42 tentang penegakan keadilan bagi seluruh manusia, QS. An-Nisâ [4]: 9 menjelaskan tentang sikap jujur dan ajaran moral lainnya. Di kalangan para ahli Islam disebut dengan kategori ayatayat "mubkamat" (ayat-ayat yang kokoh dan tidak dapat diabaikan sama sekali). ${ }^{49}$

Jika ulama klasik mengklasifikasikan makkiyyah dan madâniyyah dengan tiga bentuk, yaitu waktu, tempat dan objek pembicara. Maka Husein memandang bahwa makkiyyah dan madâniyyah tidak semata-mata dilihat dari sisi waktu dan tempat melainkan pada kondisi sosial penerima (masyarakat) atau pembacanya. ${ }^{50}$ Bagi Husein ayat makkiyyah adalalah ayat-ayat yang diturunkan di Mekkah, yang menekankan pada ketauhidan, nilai-nilai kemanusiaan universal seprti prinsip kesetaraan manusia, keadilan, kebebasan, pluralitas, dan penghargaan pada manusia sebagai tujuan utama agama. ${ }^{51}$ Oleh karena itu, menurutnya karakter teks-teks Alqur'an pada periode itu memiliki gagasan yang progresif dan revolusioner. ${ }^{52}$ lebih jauh lagi ia kemudian menggolongkan ayat makkiyyah sebagai teks universal yang kokoh (mubkamat) dan tidak membutuhkan penafsiran lebih lanjut. Pendapatnya ini jelas menggunakan prinsip liberalisme dalam pemahamannya, karena prinsip ini mensyaratkan cara

${ }^{47}$ Wawacara dengan Husein Muhammad tanggal 8 Juli 2019.

${ }^{48}$ Bandingkan dengan Muhammad, Ijtibad Kyai Husein Upaya Membangun Keadilan Gender.

${ }^{49}$ Husein Muhammad, Perempuan, Islam Dan Negara, Pergulatan Identitas Entitas (Yogyakarta: Qalam Nusantara, 2016), 124.

${ }^{50}$ Muhammad, Ijtihad Kyai Husein Upaya Membangun Keadilan Gender, xx.

${ }^{51}$ Ibid., xxvi.

${ }^{52}$ Muhammad and Qadir, Modul Kursus Islam Dan Gender; Dawrab Fikih Perempuan, 95. 
berpikir yang berbeda dan cenderung mempertanyakan hal-hal yang selama ini dianggap sudah selesai. Tetapi setelah dilakukan analisis mendalam Husein Muhammad dan beberapa ulama kontemporer yang progresif, justru menemukan bahwa hasil penafsiran terhadap Alquran selama ini belum mampu menawarkan solusi pada persoalan kemanusiaan pada umumnya, sehingga diperlukan seperangkat alat penafsifran yang baru.

Husein Muhammad meyakini bahwa ayat-ayat makkiyyah itu ayat mubkamat yang bersifat normatif-universal. Hal ini sejalan dan tercermin dalam prinsip pada maqâshid syarìah. Sehingga memahami ayat-ayat Alqur'an bagi Husein harus seiring dengan prinsip penegakan maqâshid syar̂̀ab itu sendiri.

Pada kajian lebih mendalam lagi, Husein Muhammad menegaskan bahwa ayat ayat makkiyyah yang mubkamat itu adalah teks universal. Jika mayoritas ulama ahli hukum biasa berpendapat "apabila terjadi pertentangan antara teks universal dan teks-teks partikular" maka teks partukular membatasi teks universal". Husein Muhammad mengikuti pendapat al-Syatibi yang menolak pandangan di atas. ${ }^{53}$ Artinya baginya teks partikular tidak dapat membatasi teks universal. Alasan yang dipegangnya bahwa ia percaya pesan-pesan agama yang ditulis dalam teks Alqur'an itu selalu mengandung tujuan dan ruh kemanusian. Tujuan ini dapat dipelajari dan diwujudkan karena ia bersifat rasional, dan bukan hal yang harus terkait dengan kebenaran skriptural.

Sementara teks partikular adalah menunjukkan pada kasus tertentu. Teks ini muncul sebagai respons adanya suatu peristiwa atau kasus. Dengan demikian teks ini akan selalu ada dan terkait dengan konteks tertentu, maka dimaknai secara kontekstual termasuk teks-teks hukum bersifat partikular. Seperti, isu tentang kepemimpinan laki-laki atas perempuan (QS. An-Nisâ [4]: 34), perwalian perempuan oleh laki-laki, poligami (QS. An-Nisâ [4]: 3), waris dan lain-lain. Ayat-ayat ini masuk pada kategori mutasyâbbihât (interpretable, dapat diinterpretasikan dan oleh karena itu bisa menghasilakan kesimpulan yang berbeda-beda). ${ }^{54}$

\section{Muhkamat dan Mutasyâbihât}

Selanjutnya, kajian lain yang telah direkonstruksi oleh kaum Islam pregresif termasuk Husein Muhammad adalah persoalan mublkamat dan mutasyâbbihât. Salah satu pokok perselisihan di kalangan umat Islam yang terkait erat dengan masalah ta'mîl yang sudah disinggung diatas adalah ayat-ayat suci Alqur'an yang bermakna jelas atau pasti (mublkamât) dan yang bermakna samar atau tidak pasti (mutasyâbbihât), yakni yang interpretable. Ayat-ayat mubkamât adalah kumpulan hukum-hukum yang disampaikan kepada Nabi Muhammad, yang memuat prinsip-prinsip prilaku manusia yaitu yaitu ibadah, muamalah, akhlak dan hal-hal yang membentuk risalahnya. Jenis

${ }^{53}$ Muhammad, Perempuan, Islam Dan Negara, Pergulatan Identitas Entitas. Lihat juga Muhammad and Qadir, Modul Kursus Islam Dan Gender; Dawrah Fikih Perempuan. Bandingkan dengan Abu Ishak Ibrahim ibn musa ibn Muhammad Al-Syatibi, Al-Muwafaqat Fi Ushul Al-Syariah (Qahirah: Dar ibn Affan, 1997), 261-72.

${ }^{54}$ Muhammad, Perempuan, Islam Dan Negara, Pergulatan Identitas Entitas, 125. 
ayat mubkamat ini berfungsi sebagai pembeda antara yang halal dan yang haram. Sedangkan ayat-ayat mutasyâbbihât adalah kumpulan seluruh hakikat yang diberikan Allah kepada Nabi Muhammad yang sebagian besar darinya bersifat ghaybiyah, yaitu hal-hal yang belum diketahui oleh kesadaran manusia ketika Alqur'an diturunkan. Kitab ini merepresentasikan kenabian Muhammad dan sekaligus membedakan antara yang nyata dan yang absolut dengan dugaan semata. ${ }^{55}$

Menurut Husein Muhammad ayat-ayat mubkamat lebih merujuk pada prinsipprinsp dasar kebenaran yang bersifat universal, seperti tauhid, keadilan, persamaan hak, dan kesetaraan manusia di muka hukum. Istilah muhkamat sendiri diterjemahkan oleh Husein Muhammad sebagai ayat-ayat kokoh dan tidak dapat diabaikan sama sekali. Mengikuti apa yang dituturkan al-Ghazali, menurut Husein Muhammad dalam mubkamat ini terdapat semua tujuan agama yang kepadanya seluruh gagasan manusia harus disandarkan (maqûsbid al-Syarîab) agama.

Sedangkan ayat-ayat mutasyâbbihât diartikan oleh Husein Muhammad sebagai ayat ayat yang interpretable, dapat dipresentasikan, dan dapat menghasilkan kesimpulan yang berbeda-beda. Mutasyâbbibât dalam pandang Husein adalah ayat-ayat partikular, semua ayat-ayat hukum adalah ayat partikular, isu-isu tentang kepemimpinan, (qiyamah) laki-laki atas perempuan, perwalian perempuan dan laki-laki (waliyah), poligami, kewarisan dan lain lain termasuk pada ayat partikular atau mutasyâbbihât. Dengan kata lain, ayat-ayat mutasyâbbihât cenderung bersifat teknis partikular yang berkenaan dengan kasus dan peristiwa tertentu seperti kewarisan, poligami, persaksian perempuan dll, dimana ayat-ayat itu jika ditafsirkan dapat melahirkan pemahaman yang berbeda. Perbedaan itu terutama jika sesorang tidak menggunakan pendekatan kontekstual (ta'wi). Husein dan para ulama kontemporer sama-sama menganjurkan penggunaan ta'wil untuk ayat-ayat mutasyâbbihât versi mereka. ${ }^{56}$

Definisi seperti ini berbeda dengan pendapat ulama pada umumnya yang biasa mendefinisikan bahwa ayat-ayat mutasyâbbihât itu ayat-ayat non hukum dan ayatayat mubkamat adalah ayat ayat hukum, dan biasa memahami ayat-ayat mutasyâbbihât itu sebagai ayat-ayat yang mengandung kemungkinan makna banyak atau yang maknanya ambigu, atau ayat-ayat yang secara tekstual mengandung keserupaan antara Tuhan dengan makhluknya. ${ }^{57}$

\section{Teori Ta'wil}

Membahas persoalan $t a^{\prime} w$ l, berarti mengkaji tuntas semua bagian teks, bahkan tidak terbatas pada batas-batas kepadatan makna yang tersembunyi. Ta'w $l$ dapat dilakukan setelah melalui proses tafsir, yakni menyelami kedalaman teks melalui gerak mental atau ijtihad. Ijtihad merupakan sebuah proses yang dituntut oleh perkembangan realitas serta pluralitas masyarakat Islam dan perbedaan mereka. Berijtihad dalam melakukan ta'w $l$ atas teks tidak dibedakan antara bidang fikih dan

${ }^{55}$ Muhammad Syahrur, Prinsip Dan Dasar Hermeneutika Alquran Kontemporer (Yogyakarta: Elsaq press, 2004), 71-72.

${ }^{56}$ Muhammad, Ijtihad Kyai Husein Upaya Membangun Keadilan Gender, xxv.

${ }^{57}$ Munir Al-Syawaf, Tahafut Al-Qiraah Al-Mu'asirah (Cyprus: Limassol, 1993), 177. 
hukum dengan bidang-bidang lainnya, sebab ijtihad berdasarkan pada nalar untuk menembus kedalam teks. ${ }^{58}$ Teks selalu terbuka terhadap pembacaan baru. Akan tetapi pembacaan baru ini lebih bersifat interpretatif yang berusaha menyelami dunia teks secara total dan berusaha mendalaminya secara komprehensif-intertekstualis yang memungkinkan terjadinya percampuran antar horison (fusion of Horizons). ${ }^{59} \mathrm{Hal}$ ini adalah kondisi yang selalu mungkin (condition of posibilitiess) yang terdapat pada teks.

Oleh karena itu sejak awal Husein lebih memilih ta'wil daripada tafsir. Menurutnya, pendekatan ta'wil ingin membaca sebuah teks pada makna esensial tujuan moralnya, bukan semata- mata makna literalnya. Teks dengan demikian perlu dipahami dari aspek rasio-legisnya (illah) di satu sisi serta kemaslahatan dan aspek keadilan sebagai tujuan akhir dengan mana hukum ditegakkan. Dan analisis pada aspek aspek ini pada akhirnya akan selalu ditemukan kaitannya yang sangat erat dengan dinamika dan dialektika sosial. ${ }^{60}$

Lebih lanjut, ia berpendapat bahwa ta'wil itu disebut 18 kali dalam Al-Qur'an. Sedang tafsir hanya sekali. Ta'wil digunakan pada periode awal Islam. Ta'wil lebih luas dan lebih mendalam daripada tafsir. Ta'wil tidak sekedar berarti, sebagaimana arti literalnya, mengembalikan kepada makna awal dan tidak juga sekedar tafsir metaforis (majas) belaka. Tetapi lebih dari itu adalah memahami teks melalui banyak hal, seperti latarbelakang peristiwa yang mendahului teks, konteks bahasa atau kalimat (al-siyâq allisâniy/al-lughawiy), hubungannya dengan ayat lain dan tidak kurang pentingnya adalah konteks sosial, budaya, politik, ekonomi (al-siyâq al-z̧arfîy al-ijtimâ'ŷy, wa al-tsaqâfîy wa al-siyâsîy, wa al-iqtishâdîy), dan lain-lain. Pembacaan atau pemahaman melalui sejumlah alat analisis ini sangat signifikan dalam mendiskusikan banyak problem. Termasuk isu feminisme ini. Tanpa analisis ini teks-teks agama akan kehilangan maknanya, bahkan bisa menyesatkan. Terminologi "ta'wil" hari ini identik, jika tidak boleh dikatakan sama, dengan "hermeneutika". Tafsir menurut saya lebih banyak menekankan menjelaskan makna literal, daripada makna substansial. Analisis historis teks kurang dipandang penting, dan sekedar apabila dibutuhkan"

Husein Muhammad membedakan secara tegas istilah tafsir dan ta'wil dalam buku bukunya. Menurutnya meskipun tafsir dan ta'wil seringkali dimaknai sama, yaitu menjelaskan, mengungkapkan atau menerangkan sesuatu. Namun sebenarnya dua istilah ini berbeda. Berikut ini pendapatnya tentang tafsir. Tafsir di matanya lebih berkaitan dengan riwayah (informasi, nukilan atau berita) dalam memahami teks Alqur'an, tafsir lebih memperhatikan makna tekstual atau literal dan kurang

\footnotetext{
${ }^{58}$ Abdur Razzaq and Deden Mula Saputra, "Studi Analisis Komparatif Antara Ta'wil Dan Hermeneutika Dalam Penafsiran Al-Qur’an,” Wardab 17, no. 2 (2016): 89-114.

${ }^{59}$ Ketika aktivis memahami dan menafsirkan berlangsung, sebnarnya yang terjadi adalah suatu percampruran dan pertautan antara horison yang terlibat dalam penafsiran tersebut, setidaknya yang terlibat adalah horison pengarang dan segala horison yang melingkupi pengarang tersebut, horison teks dan horison-horison yang melingkupi teks itu, serta horison penafsir dan horison hosrson yang lain yang melingkupinya. Horison -horison yang lain itu kebaradaan dalam lingkup tertensu, misalnya negara, agama, kondi psikologis tertentu. Lihat Fakhruddin Faiz, Hermeneutika Qurani Anatara Teks, Konteks Dan Kontektualisasi (Yogyakarta: Qalam, 2002), 35-36.

${ }^{60}$ Muhammad, Ijtihad Kyai Husein Upaya Membangun Keadilan Gender, xvii-xviii.
}

Khazanah, Vol. 18 (1), 2020 
memperhatikan makna alegoris atau metaforis. Karena dalam teori tafsir jika makna kata itu memiliki makna literal dan metafor maka yang diutamakan untuk dipilih adalah makna literal. Karena tafsir identik dengan pendekatan tekstual dalam memahami makna kata, maka tafsir seingkali mengabaikan psikososial yang melingkupi. Ia setuju dengan pendapat Abu Nasr al-Qusyairi bahwa dalam tafsir itu yang diutamakan mendengarkan dan mengutip. Pendapat Husein Muhammad ini memiliki kesamaan dengan pendapat Abu al'ala al-Maududi. ${ }^{61}$

Husein Muhammad lebih memilih ta'wil daripada tafsir dalam memahami makna dari teks-teks Alqur'an. Karena menurutnya ta'wil memiliki tata kerja yang memungkinkan sesorang memahami makna universal dan partikular dari lafadz itu. Baginya, ta'wil itu memiliki tata kerja berkaitan dengan dirâyah (pemahaman), yakni pemahaman pada isi-dan substansi teks. Menurutnya dalam ta'wil jika satu kata memliki dua makna, literal dan metafor, maka ta'wil lebih menekankan pada analisa makna substantif, pada maksud dan tujuannya. kehendak ta'wil bukan sekedar memahami teks dari makna tekstualnya, melainkan pada logika dan filosofi maknanya. Menurutnya taw'il meniscayakan pengetahuan tentang konteks yang menyertai isu itu sendiri, konteks sosial dan budaya politik yang melingkupinya ${ }^{62}$ meskipun tampak pendapatnya ini identik dengan prinsip prinsip hermeneutika namun secara tegas ia menjelaskan pada penulis bahwa "saya tidak mengerti hermeneutika tapi begitulah seharusnya orang memahami ayat-ayat Alqur'an kapanpun dan dimanapun. Sehingga pemahamannya akan dapat memberikan solusi bagi kehidupan manusia, walaupun begitu tetap saja tafsir itu adalah produk ibnu zamânibi.",33

Husein menegaskan bahwa memahami Alqur'an dengan cara mena'wil itu lebih baik dari pada menafsir Alqur'an. Karena menurutnya ta'wil adalah upaya memahami teks dengan melibatkan permenungan yang mendalam. Seorang penawil disamping melakukan pembacaan terhadap teks Alqur'an berdasarkan naql/riwayat, dia melakukan ijtihad intelektual untuk mengungkap makna, tujuan, atau maksud sejati yang dikehendaki Tuhan. Ia tidak benar-benar mengartikan tafsir, hanya ia mengutip beberapa pendapat ulama tentang tafsir yang menekan bahwa tafsir itu hanya berkaitan dengan menukil dan mendengar, berkaitan dengan kata-kata, dan riwayah. Meskipun demikian ia mengakui bahwa pada masa-masa awal seringkali terjadi pemahaman tafsir dalam arti ta'wil dan sebaliknya.

Husein Muhammad telah memilih takwil sebagai metode untuk memahami Alqur'an dari pada tafsir, nampak ia memahami bahwa tafsir hanyalah upaya pemahaman Alqur'an secara literal semata, dengan bersandarkan pada beberapa pendapat ulama yang mengecam pemahaman Alqur'an yang hanya memperhatikan makna lafdaz semata. ${ }^{64}$

${ }^{61}$ Ani Umi Maslahah, “Al-Qur'an, Tafsir Dan Ta’wil Dalam Perspektif Sayyid Abu Al-A'la AlMaududi,” Hermeneutik Jurnal Ilmu AlQur'an Dan Tafsir 9, no. 2 (2015): 21-30.

${ }^{62}$ Muhammad, Perempuan, Islam Dan Negara, Pergulatan Identitas Entitas; Muhammad, Ijtibad Kyai Husein Upaya Membangun Keadilan Gender.

${ }^{63}$ Wawancara Penulis dengan Husein Muhammad tanggal 28 April 2018

${ }^{64}$ Muhammad, Ijtibad Kyai Husein Upaya Membangun Keadilan Gender, xxvi. 
Husein Muhammad mengikut Fakh al-Din al-Razi (Razes) pada pilihannya memilih ta'wil dalam memahami pesan-pesan Alqur'an. Ia nampak berpegang teguh pada pada pendapat al-Razi yang diuraikan oleh penulis buku al-Munkhatib sebagai berikut:

Penulis buku "al-Muntakhab al-Jalâl", meringkas pandangan al-Razi ini dalam sebuah syair:

\section{إذا ما النقل خالف حكم عقل \# نؤله فنكسبه رجوعا}

Jika naql (teks) bertentangan dengan hukum akal, Kita menakwilnya, kita ambil sebagai rujukan

Menurut al-Razi, kebenaran (kepastian) makna suatu lafazd hanya bisa diterima manakala ia tidak mengandung seluruh kemungkinan di atas. Dan untuk memperoleh ini, harus dilakukan penelitian yang serius. Tetapi mengatakan bahwa usaha-usaha penelitian itu dapat menghasilkan kesimpulan yang "tidak mengandung kemungkinan" adalah juga analitik (₹̧annîy)." ${ }^{05}$

Seperti halnya ulama tafsir kontemporer lainnya yang telah memilih basis epistemologi tafsirnya pada nalar kritis. Husein Muhammad juga termasuk tokoh Indonesia yang mengembangkan model penafsiran ini. Ta'wil bagi Husein suatu metode interpretasi yang telah dipilihnya. Ta'wil yang notabene merupakan kerangka metodologi-hermeneutis itu ia kembangkan pada beberapa langkah operasional pemahamanya pada isu isu HAM dan relasi gender dalam Alqur'an.

Selain itu paparan diatas juga mengantarkan pemahaman pada kita, bahwa bagi Husein Muhammad memahami Alqur'an dengan cara mena'wil akan lebih dapat menyampaikan seseorang pada pengetahuan tentang sejumlah kondisi dan konteks, antara lain bahasa, audiens dan situasi-situasi di luarnya. Maka tanpa cara seperti ini seseorang tidak dapat memahami Alqur'an secara geniun dan komperhensif dan akan kehilangan relevansinya. Dengan ta'wil sesorang akan mengerti bahwa sebuah teks itu dinamis dan berproses secara terus menerus. ${ }^{66}$

Sampai batas ini dapat disimpulkan bahwa Husein Muhammad memiliki pandangan yang sama dengan mufasir kontemporer pada umumnya, karena ia telah membangun tafsirnya dengan asumsi bahwa menafsir sebagai upaya memahami maksud Allah dalam Alqur'an harus menggunakan hermeneutika, sehingga tafsir Alqur'an itu dinamis, relatif dan tentafif.

Dengan prinsip ta'wil seperti diungkapkan di atas Husein kemudian memahami ayat Alqur'an yang secara literal tampak tidak ada kaitan dengan isu gender, namun ditangannya ayat itu bisa menjadi ayat-ayat yang membela dan menyelesaikan persoalan manusia terutama perempuan.

Dari paparan di atas, kiranya dapat dipahami Husein Muhammad telah melakukan pergesaran paradigma (paradigm shift) dalam memahami konsep mubkammutasyabbih, dan nâsikh-mansûkh. Berawal dari pernyataannya bahwa ayat makkiyyah adalah adalah ayat ketauhidan dan kemanusiaan universal sebagai tujuan agama, ayat ini olehnya digolongkan pada ayat-ayat universal. Sedangkan ayat-ayat madâniyyah

${ }^{65}$ Wawancara penulis dengan Husein Muhammad tanggal 9 Mei 2018

${ }^{66}$ Muhammad, Perempuan, Islam Dan Negara, Pergulatan Identitas Entitas, 123. 
merupakan ayat ayat yang mengandung ajaran aturan aturan kehidupan personal, keluar dan hal hal yang lain yang bersifat partikular (al-abwal al-syakbsiyah), olehnya ayat madâniyyah digolongkan pada ayat-ayat partikular atau ayat mutasyabbihât. Maka jika terjadi pertentangan anatara ayat universal dan ayat partikular, yang diutamakan adalah ayat universal bukan ayat partikular (padahal umunya ulama fikih berpendapat sebaliknya). Solusi yang ia tawarkan berarti ayat universal yang isinya ayat makkiyyah dan ayat mubkamat versinya itu dapat menjadi nâsikh (penunda) atas ayat ayat madâniyyah yang partikular dan mutasyabbihât. Sampai batas ini ia tampak mengikuti apa yang sudah dipolakan oleh Mahmud Muhammad Toha bahwa ayat-ayat makkiyyah dapat menaskh ayat-ayat madâniyyah.

Meskipun demikian, menurut hemat penulis, konsep-konsep Husein tetap besifat "subjektif", sebab dalam Alqur'an sendiri tidak ada penjelasan secara tegas yang menyatakan bahwa mubkamat adalah ayat-ayat hukum dan mutasyabbibât ayat ayat non hukum. Juga tidak ada penjelasan dalam Alqur'an tentang mana kelompok ayatayat makiyyah dan mana kelompok ayat madâniyyah, mana kelompok ayat yang menjadi nâsikh dan mana yang menjadi mansûkh demikian seterusnya.

Pandangan Husein yang telah dipaparkan di atas adalah pandangan yang berseberangan dengan ulama konservatif di kalangan NU. Pandangan seperti ini selanjutnya berimplikasi pada beberapa metode dan pendekatan yang digunakannya dalam memahami Alqur'an. Umumnya kalangan ulama berpandangan bahwa Alqur'an itu qoth'i al-dilalah dan qoth'i al-wuruid.

Sebenarnya menurut Husein, ketika para ulama mengkaji dan berdebat pada kajian asbâb al-nu₹ûl, Makkiyyah-madâniyyah, mubkam-mutasyabbih dan juga nâsikhmansûk.h cukup baginya menunjukkan sesungguhnya mereka sudah mengakui historisitas Alqur'an itu sendiri. ${ }^{67}$ Artinya prinsip liberalisme dalam pemahaman Husein sebenarnya implikasi langsung dari pandangan ontologisnya pada Alqur'an dan tafsir.

Dalam kaitan dengan kajian artikel ini, semakin menunjukan bahwa asumsi dan paradigma subjek memandang objek mempengaruhi metodologi yang dipilihnya untuk memahami objek. Hal ini juga akan mempengaruhi standar parameter kebenaran yang ditetapkan subjek terhadap objek. Jika ini terapkan pada Husein Muhammad, maka wajar jika paradigma fungsional yang digunakannya dalam memahami Alqur'an dan tafsir akan mempengaruhi metodologi berpikirnya dalam memahaminya, maka hampir bisa dipastikan Husein memiliki standar parameter kebenaran yang dipengarui oleh pandangan ontologis dan metodologis dalam memahami teks. Jika pandangan Husein sebagai subjek pada Alquan dan tafsir sebagai objek berbeda dengan ulama klasik, maka hampir dipastikan metodologi dan standar kebenaran yang dipegannya juga berbeda dengan mufasir klasik.

\section{Implikasi Liberalisasi Prinsip Penafsiran Alqur'an Terhadap Hasil Tafsir}

Dalam buku Fiqh Perempuan Refleksi Kyai atas Wacana Agama dan Gender, Husein Muhammad menegaskan bahwa agama (tafsir agama) sebagai salah satu

${ }^{67}$ Muhammad and Qadir, Modul Kursus Islam Dan Gender; Dawrab Fikih Perempuan, 85. 
komponen yang membentuk budaya suatu masyarakat, perlu dilihat kembali, dievaluasi, dan ditafsirkan ulang untuk kepentingan terwujudnya kehidupan yang lebih adil bagi seluruh manusia. Utamanya ini semua untuk kepentingan perempuan dalam kaitannya dengan relasi gender, sehingga pemikiran keagamaan tidak lagi menjadi penghambat proses kesetaraan dan keadilan gender. Sedangkan kelebihan dari buku ini adalah kekayaan rujukannya pada kitab kuning (fikih klasik) dalam menganalisis gender melalui teks-teks agama. ${ }^{68}$

Pernyataan-pernyataan yang diungkapkan Husein dalam buku ini hampir semuanya membuat para kyai pesantren tercengang. ${ }^{69}$ Bagaimana tidak, dalam buku ini Husein memulai dengan pandangan dasar agama terhadap posisi perempuan dan laki-laki, yaitu argumentasi teks agama (baik Al-Qur'an maupun hadits) yang memposisikan perempuan dan laki-laki setara.

Ayat Al-Qur'an yang dikutip misalnya adalah surat al-Hujarât [49]:13 yang artinya: Hai manusia, kami telah menciptakan kamu dari laki-laki dan perempuan, dan kami jadikan kamu berbangsa-bangsa dan bersuku-suku, supaya kamu saling mengenal. Sesunggubnya yang paling mulia diantara kamu di sisi Allah adalah yang paling takwa. Juga ayat dalam surat an-Nahl [16]:97 yang artinya: Siapa saja, laki-laki atau perempuan jang beramal saleh dan dia beriman, niscaya Kami berikan kehidupan yang baik.

Setelah menjelaskan kedudukan sama antara laki-laki dan perempuan, di bab berikutnya Husein berbicara tentang bolehnya perempuan menjadi imam shalat lakilaki. Pandangannya tentang imam shalat perempuan dilandasi pada pernyataan Abu Hamid al-Isfirayani (344-406 H.), tokoh utama aliran fikih Iraqi dari madzhab Syafi'i (Syaikh al Iraqiyyin) menyatakan: "Seluruh ulama fikih dari berbagai madzhab fikih Islam, kecuali Abu Tsaur (240 H/854 M.), salah seorang mujtahid besar, sepakat berpendapat bahwa kepemimpinan perempuan dalam shalat bagi jama'ah kaum lakilaki adalah tidak syah" (Syarifuddin an-Nawawi, al-Majmu' Syarb al-Mubadzab). ${ }^{70}$

Rujukan ulama yang membolehkan perempuan menjadi pemimpin shalat lakilaki adalah Ibnu Jarir ath-Thabari (w. 310 H./923 M.), seorang ahli tafsir, sejarawan, dan pendiri madzhab fikih. Ulama lain yang membolehkan adalah Imam al-Muzani (175-264 H.), murid utama Imam asy-Syafi'i. Sedangkan dasar hukum yang digunakan oleh Husein dalam membolehkan perempuan menjadi imam shalat laki-laki adalah hadits Nabi yang berbunyi: Diriwayatkan oleh Abdurrahman bin Khallad, ia mengatakan: Nabi pernah mendatangi rumahnya (rumah Abdurrabman) dan memberinya seorang muadzin, dan menyurubnya (Ummu Waraqah) menjadi imam bagi penghuni rumabnya. Abdurrahman mengatakan: Aku benar-benar melibat, muadzinnya adalab seorang laki-laki tua (al-Mundziri, Mukbtashar Sunan Abu Dawud). ${ }^{71}$

${ }^{68}$ Husein Muhammad, Fiqh Perempuan; Refleksi Kiai Atas Wacana Agama Dan Gender (Yogyakarta: LKIS, 2001).

${ }^{69}$ Husein Muhammad pernah diundang oleh kyai-kyai NU se-Jawa Timur untuk mempertanggung-jawabkan pendapat-pendapatnya dalam buku Figh Perempuan Refleksi Kiai atas Wacana Keagamaan dan Jender, yang bertempat di Pesantren Lirboyo Kediri Jawa Timur, kira-kira awal tahun 2003 (Husein Muhammad sendiri lupa kapan diadakan).

${ }^{70}$ Muhammad, Figh Perempuan; Refleksi Kiai Atas Wacana Agama Dan Gender, 29.

${ }^{71}$ Ibid., 31. 
Menurut Husein, masalah paling utama dari pelarangan ulama madzhab terhadap perempuan menjadi pemimpin shalat laki-laki adalah soal "fitnah". Persoalannya kemudian adalah bagaimana kalau dalam mekanisme tertentu atau situasi ruang dan waktu tertentu, pertemuan laki-laki dan perempuan dapat dipastikan tidak akan membawa fitnah? Apakah perempuan dapat menjadi imam shalat bagi laki-laki dan mempunyai hak publik? Inilah pertanyaan-pertanyaan mendasar yang merupakan gagasan besar Husein dalam menyikapi persoalan teks agama yang mensubordinasi dan memarjinalkan perempuan. Gagasan perempuan menjadi imam shalat laki-laki ini mendapatkan reaksi dan penolakan yang sangat luar biasa dari berbagai ulama pesantren, terbukti misalnya Husein diundang di beberapa pesantren untuk mempertanggungjawabkan gagasannya tersebut. ${ }^{72}$

Jika dianalisa lebih lanjut, penafsiran Husein Muhammad pada dua ayat di atas, (al-Hujarat [49]:13 dan surat an-Nahl [16]:97 menggunakan prinsip liberalisme, ayat ini dianggap sebagai ayat ayat yang universal, yakni ayat tauhid yang makkiyyah dan bersifat kokoh (mubkamat) maka memperbolehkan perempuan menjadi imam shalat diturunkan dari prinsip universal ini, bukankah Husein Muhammad telah menegaskan bahwa tidak mungkin hal yang bersifat partikular dapar menghapus yang universal. Artinya jika pesan universal dari teks agamanya adalah seruan untuk saling mengenal dan hanya mengukur manusia itu dari kesempurnaan amal (bukan jenis kelamin) maka, perempuan menjadi imam shalat adalah bagian dari hasil penafsiran yang taat pada prosedur penafsiran dengan prinsip liberalisme .

Pada bab-bab berikutnya buku Fikih Perempuan Refleksi Kiyai atas Wacana Agama dan Gender ini menerangkan masalah "Khitan bagi Perempuan". Husein menjelaskan perdebatan para ulama klasik tentang hukum khitan bagi perempuan, dan menjelaskan pula tentang landasan hukumnya yang tidak memiliki dasar kuat, karena tidak ada hadis yang mewajibkan perempuan khitan. Kalaupun ada hadisnya, tingkat kesahihan hadis itu diragukan, seperti permyataan Ibnu al-Mundzir yang dikutip oleh Ibnu Hajar al-Asqalani dalam kitab Takblish al-Habir. "Tidak ada satu pun hadis yang bisa menjadi rujukan dalam hal khitan, dan tidak ada satu pun sanad yang bisa diikuti." ${ }^{73}$

Selain itu, Husein juga membahas masalah aurat perempuan, masih dalam perdebatan para ulama yang ditulis dalam kitab kuning. Menurut Husein, batas aurat perempuan masih menjadi perdebatan ulama madzhab, dan ada perbedaan batas aurat antara perempuan merdeka dengan perempuan budak. Perempuan merdeka batas auratnya adalah seluruh tubuhnya, kecuali muka dan telapak tangan. Sedangkan batas aurat perempuan budak sama dengan laki-laki, yaitu sebatas pusar sampai lutut.

Menurut Husein, perdebatan tentang batas aurat perempuan adalah kontekstual. Maksudnya adalah pemahaman ulama terhadap aurat perempuan

${ }^{72}$ Dua kali Husein diundang oleh Alumni Ponpes Lirboyo Kediri, yang terdiri dari kyai-kyai pesantren se-Cirebon untuk mempertanggungjawabkan gagasannya tentang imam perempuan, namun secara umum seluruh gagasan Husein dipertanyakan dalam acara tersebut. Pertemuan pertama diadakan pada bulan puasa atau bulan November 2003 di daerah Weru Cirebon, dan pertemuan kedua pada Desember 2003 di Tegalgubug Cirebon.

${ }^{73}$ Muhammad, Fiqh Perempuan; Refleksi Kiai Atas Wacana Agama Dan Gender, 44. 
ditentukan juga oleh realitas yang ada pada saat itu. Hal ini bisa lebih jelas ketika ulama memperbolehkan muka, telapak tangan, telapak kaki, atau lengan perempuan merdeka untuk dibuka karena alasan keperluan (li al-hajah), atau karena menutup anggota tersebut termasuk sesuatu yang merepotkan dan memberatkan (daf'an li alharaj wa al-masyaqqab).

Ini semua memperlihatkan dengan jelas bahwa teks-teks yang terkait dengan aurat adalah tidak berdiri di ruang hampa yang tanpa pijakan terhadap relaitas. Apabila "kesulitan" dan "keperluan" merupakan penentu dalam menginterpretasikan teks-teks aurat, maka aurat adalah bukan terminologi agama. Artinya jelas, yaitu batasan aurat tidak ditentukan oleh teks-teks agama, tetepi oleh konteks sosial budaya yang relatif berbeda dari satu tempat ke tempat lain.

Penafsiran Husein Muhammad memiliki kecenderungan lebih didominasi oleh wacana pemikiran dan metodologi tafsir yang berusaha menggugat dominasi pemikiran tafsir klasik dan pertengahan, bersifat kritik terhadap metodologi lama atau dekonstruksi pada reinterpretasi sebagian ayat-ayat Alquran. Penafsirannya diwarnai oleh pemikiran Islam progresif-transformatif. Oleh karena itu ia telah melakukan pergeseran paradigma (paradigms sift) yang berimplikasi pada lahirnya hasil penafsiran yang berbeda dengan penafsiran ulama klasik yag telah lebih awal populer di kalangan masyarakat muslim Indonesia.

\section{Simpulan}

Usaha Husein Muhammad menggugat dominasi pemikiran tafsir klasik dan pertengahan, mengkritik metodologi lama atau mendekonstruksi pada reinterpretasi sebagian ayat-ayat relasi gender yang dinilainya bias gender itu, sebenarnya dalam wacana keilmuan dianggap sah-sah saja, bahkan dianggap keniscayaan, semacam upaya menemukan normal science pada paradigma Kuhn. Asumsi dan paradigma pemikiran tafsirnya dibangun atas penekanannya pada historisitas teks Alquran sebagai pandangan ontologisnya, yang pada giliran tertentu mengharuskan memiliki pemahaman yang berbeda dengan ulama abad klasik tentang asbâb al-nu₹ûl, nâsikhmansûk.h, makkiyah-madâniyyah, juga mubkam-mutasyabbih. Pilihannya metodologi tafsir yang berbeda dengan ulama klasik juga bagian lain yang tidak dapat dihindari sebagai konsekuensi dari pandangan ontologis tersebut. Sudah barang tentu berimplikasi pada penentuan standar parameter kebenaran yang juga berbeda dengan standar parameter kebenaran tafsir para mufasir klasik.

Namun untuk sebuah rekonstruksi sosial, menurut penulis dibutuhkan juga penyelidikan faktual yang menyeluruh terhadap data sosial yang relevan. Karena tanpa penyelidikan faktual, pandangan Alqur'an hanya akan tinggal pada tataran abstrak dan tidak memiliki daya transformasi sosial yang kuat. Oleh karena itu, seperti yang sedang diperjuangkan para feminis pada umumnya selayaknya hasil penafsiran Husein yang berkaitan dengan isu-isu gender dapat diturunkan pada undang-undang dan beberapa aturan daerah sehingga dapat segera dirasakan hasilnya, yakni rekonstruksi sosial dengan wajah baru yang lebih humanis, inklusif, dan penuh perdamaian. 


\section{Daftar Pustaka}

Abdallah, Ulil Abshar. Menjadi Muslim Liberal. Jakarta: Nalar, 2005.

Abdullah, Amin. Islamic Studies Di Perguruan Tinggi Pendekatan Integratif Interkonektif. Yogyakarta: Pustaka Pelajar, 2006.

Abror, Robby Habiba. "Makna Kebebasan Berpikir Dalam Diskursus Pemikiran Islam Kontemporer." UNISIA 38, no. 84 (2018): 38-47.

Al-Syâtibi, Abu Ishak Ibrahim ibn musa ibn Muhammad. Al-Muwafaqât Fi Ushul AlSyari'ah. Qahirah: Dar ibn Affan, 1997.

Al-Syawaf, Munir. Tahafut Al-Qiraah Al-Mu’asirah. Cyprus: Limassol, 1993.

Badruzaman, Abad. "Model Pembacaan Baru Konsep Makiyyah-Madaniyyah." Epistemé: Jurnal Pengembangan Ilmu Keislaman 10, no. 1 (2015): 53-76.

Bashin, Kamla, and Nighat Said Khan. Persoalan Pokok Mengenai Feminisme Dan Relevansinya. Jakarta: Gramedia, 1995.

Bolkestein, Frits. Liberalisme Dalam Dunia Yang Tengah Berubah. Jakarta: Sumatra Institute, 2006.

Dzulhadi, Qosim Nurseha. "Kontroversi Nasikh-Mansukh Dalam Al-Qur'an." Tsaqofah Jurnal Peradaban 5, no. 2 (2009): 257-88.

Edwards, Paul, ed. The Encylopedia of Philosophy. New York: Macmillan Publishing Co, Inc and Fress Press, 1967.

Engineer, Asghar Ali. Islam Dan Teologi Pembebasan, Terj. Hairus Salim. Yogyakarta: LKIS, 1991.

Essack, Farid. Membebaskan Yang Tertindas, Al-Qur'an Liberalisme Pluralisme. Translated by Watung Budiman. Bandung: Mizan, 2000.

Faiz, Fakhruddin. Hermeneutika Qurani Anatara Teks, Konteks Dan Kontektualisasi. Yogyakarta: Qalam, 2002.

Fauzi, Ahmad. "Konstruksi Model Pendidikan Pesantren: Diskursus Fundamentalisme Dan Liberalisme Dalam Islam.” Al-Tahrir: Jurnal Pemikiran Islam 18, no. 1 (2018): 85-110.

Harisuddin, M Noor. "Pemikiran Feminis Muslim Di Indonesia Tentang Fiqh Perempuan.” Al-Tahrir: Jurnal Pemikiran Islam 15, no. 2 (2015): 237-62.

Harris, Khalif Muammar A. "Islam Dan Liberalisme: Antara Maṣlaḥah Dan Mafsadah.” Jurnal Akidah \& Pemikiran Islam 20, no. 2 (2018): 1-52.

Hasbi, Muhammad. "Kekerasan Perempuan Dalam Wacana Pemikiran Agama Dan Sosiologi." Al-Tahrir: Jurnal Pemikiran Islam 15, no. 2 (2015): 389-410. 
Husaini, Adian, and Rahmatul Husni. "Problematika Tafsir Feminis: Studi Kritis Konsep Kesetaraan Gender." Al-Tahrir: Jurnal Pemikiran Islam 15, no. 2 (2015): 367-88.

In'amuzzahidin, Muh. "Konsep Kebebasan Dalam Islam.” At-Taqaddum 7, no. 2 (2017): 259-76.

Jabiri, M. 'Abid Al. Fahmu Al-Qur'an Al-Hakim; Al-Tafsir Al-Wadih Hasbi Tartib AlNuzul. Maroko: al-Dar al-Baida’, 2008.

Jarullah, Syeikh 'Abdullah bin Ibrahim. Tangung Jawab Wanita Muslimah. Translated by Mukhtar Nasir. Solo: Pustaka Mantiq, 1996.

Kholid, Abd. "Legalitas Riwayat Asbab Al Nuzul Telaah Historis Kontek Turunnya Ayat Al-Qur'an.” Jurnal THEOLOGIA 24, no. 1 (2013): 145-74.

Ma'mur, Jamal. Rezim Gender Di NU. Yogyakarta: Pustaka Pelajar, 2015.

Maofur, Edward, Mohd Yakub, and Zulkifli Mohd Yusoff. "Pengaruh Liberalisme Terhadap Kajian Al-Qur'an Di Indonesia.” Jurnal Usuluddin 40 (2014): 1-26.

Maslahah, Ani Umi. “Al-Qur'an, Tafsir Dan Ta'wil Dalam Perspektif Sayyid Abu AlA’la Al-Maududi.” Hermeneutik Jurnal Ilmu AlQur'an Dan Tafsir 9, no. 2 (2015): 21-30.

Misrawi, Zuhairi, and Noviriantoni. Doktrin Islam Progresif Memahami Islam Sebagai Ajaran Rahmat. Jakarta: LSIP, 2004.

Muhammad, Husein. Fiqh Perempuan; Refleksi Kiai Atas Wacana Agama Dan Gender. Yogyakarta: LKIS, 2001.

. Ijtihad Kyai Husein Upaya Membangun Keadilan Gender. Jakarta: Rahima, 2001.

. Perempuan, Islam Dan Negara, Pergulatan Identitas Entitas. Yogyakarta: Qalam Nusantara, 2016.

Muhammad, Husein, and Faqihuddin Abdul Qadir. Modul Kursus Islam Dan Gender; Dawrah Fikih Perempuan. Cirebon: Fahima Institut, 2007.

Munawar-Rachman, Budhy. Argumen Islam Untuk Liberalisme. Jakarta: Grasindo, 2010.

. Reorientasi Pembaruan Islam: Sekulerisme, Liberalisme Dan Pluralisme, Paradigma Baru Islam Indonesia. Jakarta: LSAF dan Paramadina, 2010.

Nordin, Munif Zariruddin Fikri, Suhanim Abdullah, and Marzalina Mansor. "Liberalisme Agama Dalam Analisis Wacana Sisters in Islam Di Malaysia." Universiti Utara Malaysia, 2012.

Nuruzzaman, M. Kyai Membela Perempuan. Yogyakarta: Pustaka Pesantren, 2005. 
Rahman, Yusuf. "Feminist Kyai, KH Husein Muhammad: The Feminist Interpretation on Gendered Verses and the Qur' n-Based Activism." AlJami'ah: Journal of Islamic Studies 55, no. 2 (2017): 293-326.

Razzaq, Abdur, and Deden Mula Saputra. "Studi Analisis Komparatif Antara Ta'wil Dan Hermeneutika Dalam Penafsiran Al-Qur'an.” Wardah 17, no. 2 (2016): 89-114.

Rofiah, Nur. "Kekerasan Dalam Rumah Tangga Dalam Perspektif Islam.” Wawasan: Jurnal Ilmiah Agama Dan Sosial Budaya 2, no. 1 (2017): 31-44.

Susanti, Susanti. "Husein Muhammad Antara Feminis Islam Dan Feminis Liberal." Teosofi: Jurnal Tasawuf Dan Pemikiran Islam 4, no. 1 (2014): 197-219.

Syahrur, Muhammad. Prinsip Dan Dasar Hermeneutika Alquran Kontemporer. Yogyakarta: Elsaq press, 2004.

Tobroni, Muhammad. "Makna Seksualitas Dalam Al-Qur'an Menurut Husein Muhammad." Al-A'raf: Jurnal Pemikiran Islam Dan Filsafat 14, no. 2 (2017): 219-38.

Zakaria, Samsul. "Kepemimpinan Perempuan Dalam Persepektif Hukum Islam (Studi Komparatif Antara Pemikiran Kh. Husein Muhammad Dan Prof. Siti Musdah Mulia)." Khazanah 6, no. 1 (2013): 65-97.

Zulaiha, Eni. "Analisa Gender Dan Prinsip-Prinsip Penafsiran Husein Muhammad Pada Ayat-Ayat Relasi Gender." Al-Bayan: Jurnal Studi Al-Qur 'an Dan Tafsir 3, no. 1 (2018): 1-11.

. "Tafsir Feminis: Sejarah, Paradigma Dan Standar Validitas Tafsir Feminis." Al-Bayan: Jurnal Studi Ilmu Al-Qur'an Dan Tafsir 1, no. 1 (2016): 17-26. 